\title{
DEVELOPMENT, COMPUTATIONAL STUDIES AND VALIDATION OF SPECTROPHOTOMETRIC METHOD OF METFORMIN HYDROCHLORIDE IN PHARMACEUTICAL FORMULATIONS
}

\author{
AHMED ABU JUDEH, ABDULLA SARIEF, YUNUSA UMAR, OMAR ASHWAQ AND SK MANIRUL HAQUE* \\ Department of Chemical and Process Engineering Technology, Jubail Industrial College, Royal Commission of Jubail, Al -Jubail Industrial City, \\ P. B. No-10099, Zip Code: 31961, KSA.
}

\begin{abstract}
Simple, fast, and sensitive spectrophotometric method was developed for the determination of metformin in pharmaceutical formulations. The spectrophotometric procedure was based on the oxidation of metformin with potassium permanganate in alkaline medium. The developed method was also validated according to International Conference on Harmonization guidelines parameters such as linearity, accuracy, precision, limit of detection and quantitation. Studies were conducted to investigate different parameters involved in color developments and optimized. The pure drug of metformin was extracted from a pharmaceutical dosage form. The extraction procedure was developed, and a possible reaction mechanism proposed in the manuscript. The IR spectrum of the extracted metformin was taken and compared with the simulated IR spectrum obtained from the density functional theory calculation. The vibrational assignment of the modes was done based on potential energy distribution.
\end{abstract}

Keywords: Spectrophotometer, Metformin, Method development, Validation, Tablets, Computational.

\section{INTRODUCTION}

Diabetes is due to high amount of glucose in the blood. It is coming with food into the body, increase the level. The insulin hormone provides energy to the glucose inside the cells. Without insulin, blood sugar can be more than the normal, called pre-diabetes because not enough to said diabetes. Then it was continued to type 2 diabetes, mainly affect the impaired insulin secretion and action, the main reason for metabolic disorder. According to the American Diabetes Association, people having diabetes should maintain $100 \mathrm{mg} / \mathrm{dl}$ low density lipoprotein (LDL) cholesterol to start treatment with statins. ${ }^{1}$

The well-known medication for diabetes does not depend on insulin is a biguanide hypoglycemic agent. For this purpose, metformin is the better option that improves and control glycemic activity. It has been observed that 40 to $100 \%$ of metformin is released in the small intestines within 3 hours of drug delivery, thus confirming that metformin exhibits the highest glucose absorption in intestinal and enhanced insulin sensitivity. ${ }^{3-7}$ It was also suggested as an antiageing drug. Metformin hydrochloride is chemically known as 3(diaminomethylidene)-1,1-dimethylguanidine and hydrochloride salt of antihyperglycemic biguanide metformin (Figure 1). It can oxidize fatty acid and minimize the glucose level in the blood. ${ }^{8}$

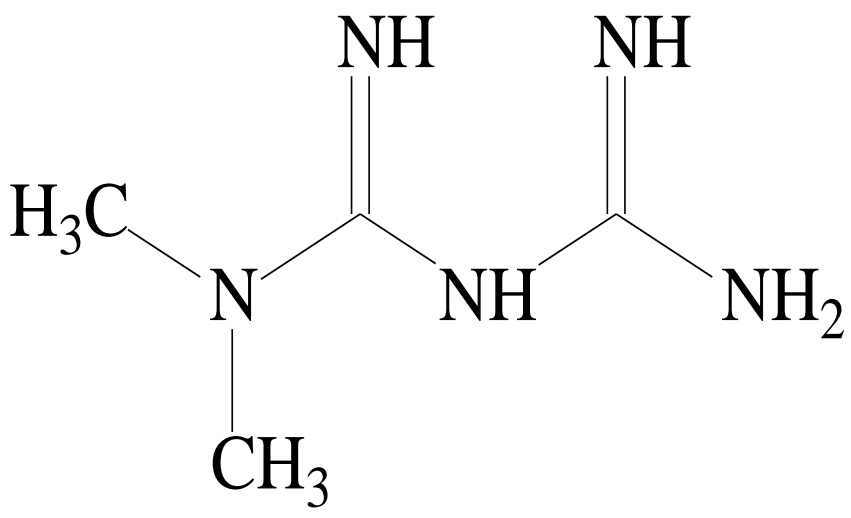

Figure 1. Structure of Metformin.
Different analytical techniques including thin layer chromatography (TLC) ${ }^{9}$, high performance thin liquid chromatography ${ }^{10-11}$, capillary electrophoresis ${ }^{12}$, high performance liquid chromatography (HPLC) ${ }^{13-19}$, ion chromatography ${ }^{20}$ and liquid chromatography mass spectrophotometry (LC-MS) ${ }^{21}$ have been introduced to determine the concentration of metformin hydrochloride in pure and pharmaceutical preparations. Most of them required tedious pretreatment and laborious cleanup procedure before analysis. It is challenging for non-developed countries to follow the developed methods due to its operating cost and challenged for a simple procedure for the analysis.

Today UV-visible spectrophotometry has a great demand for the third world countries because of simple operating procedure and low cost with high sensitivity. According to the literature survey, few visible spectrophotometric methods were reported for the determination of metformin hydrochloride in bulk, pharmaceutical formulations, and biological fluids. ${ }^{22-26}$ The violet colored complex was determined after reaction with ninhydrin at $570 \mathrm{~nm}$ in tablets within the range $8-18 \mu \mathrm{g} / \mathrm{ml} .^{22}$ Coupling agent 1 -naphthol was useful in basic medium $^{23}$, as well as chromogenic agents like 2,4 dinitrophenol and picric acid were a better option for metformin in spiked human urine. ${ }^{24}$ Simple ultraviolet (UV) spectrophotometric methods were developed and validated for quantitation of metformin as single or in a binary mixture. ${ }^{27-36}$

The proposed method presents a validated spectrophotometric method for the quantitation of metformin hydrochloride in bulk and pharmaceutical formulations. The method was based on the reaction between metformin and potassium permanganate at room temperature in basic medium. The green colored complex was measured at $601 \mathrm{~nm}$ and determined metformin hydrochloride in pharmaceutical dosage forms. For identification, extracted was analyzed by IR spectroscopy, and the IR spectrum of the extract was compared with the simulated IR spectrum obtained from B3LYP/6-311G $(\mathrm{d}, \mathrm{p})$ computation. A reliable computational method that has been successfully used to predict the vibrational spectra of organic compounds. ${ }^{37-43}$

\section{EXPERIMENTAL}

\section{Apparatus}

All spectral runs were made on Jenway 6300 Spectrophotometer, and Cecil Spectrophotometer with $1 \mathrm{~cm}$ matched glass cells. 


\section{Materials and reagents}

- Pharmaceutical preparations of metformin hydrochloride such as dialon (Julphar, Gulf Pharmaceutical Industries, UAE), Metfor (Tabuk Pharmaceutical Manufacturing Company, Saudi Arabia) and Glucare XR (Jazeera Pharmaceutical Industries, Saudi Arabia) were purchased from the local pharmacy.

- Potassium permanganate, $\mathrm{KMnO}_{4}$ (Sigma Aldrich, USA) solution was prepared as $5.0 \times 10^{-3} \mathrm{M}$ in distilled water.

- Sodium hydroxide (Sigma Aldrich, USA) solution was prepared as $1.8 \mathrm{M}$ in distilled water.

- Two tablets (500 mg/tablet) were ground into a powder with mortar and pestle, dissolved in $10 \mathrm{ml}$ distilled water. Column chromatography was performed on glass columns packed with silica gel (Sisco Research Laboratories Pvt Ltd, India). The crude sample was applied to the column as a solution (dissolved in distilled water). Solvents with different polarities were used to elute the material as mobile phase system (Water: Methanol: Glacial acetic acid $=4.1$ : 5.9: $0.3 \mathrm{v} / \mathrm{v} / \mathrm{v}$ ), resulting in separation of compounds When it reached at optimum length, removed and dried in an oven and collected the pure metformin as solid.

\section{FTIR spectroscopy and computational methods}

The IR spectrum of the extracted crystal of metformin was recorded from 400 to $4000 \mathrm{~cm}^{-1}$ at a resolution of $4 \mathrm{~cm}^{-1}$ and an average of 32 scans using a Thermo NICOLET 6700 FT-IR Spectrophotometer. The spectrum is compared with the simulated spectrum obtained from frequency calculations using the Density Functional Theory (DFT) method adopting Becke's three-parameter exchange functional $^{44}$ combined with Lee-Yang-Parr $^{45}$ correlation functional (B3LYP). The standard 6-311++G(d,p) basis set was used for all the atoms to carry out the calculation using the GAUSSIAN 09 program package. ${ }^{46}$

\section{Optimization of variables}

\section{Standard Stock Solution}

$100 \mathrm{mg}$ of metformin hydrochloride was transferred into $500 \mathrm{ml}$ volumetric flask \& diluted with distilled water up to the mark (200 ppm). Further dilution was followed according to the requirement.

\section{Effect of concentration of $\mathrm{KMnO}_{4}$}

The effect of the volume $(0.1-1.4 \mathrm{ml})$ of $\mathrm{KMnO}_{4}\left(5.0 \times 10^{-3} \mathrm{M}\right)$ on the colored complex was investigated, keeping constant $\mathrm{NaOH}(0.36 \mathrm{M})$ and metformin $(40$ $\mu \mathrm{g} / \mathrm{ml}$ ) concentration. The highest absorbance at $601 \mathrm{~nm}$ was achieved with 0.8 $\mathrm{ml} \mathrm{KMnO}_{4}$. Therefore, $1.1 \mathrm{ml}$ of $\mathrm{KMnO}_{4}\left(5.0 \times 10^{-3} \mathrm{M}\right)$ was used as an optimum value for the experiment (Figure 2).

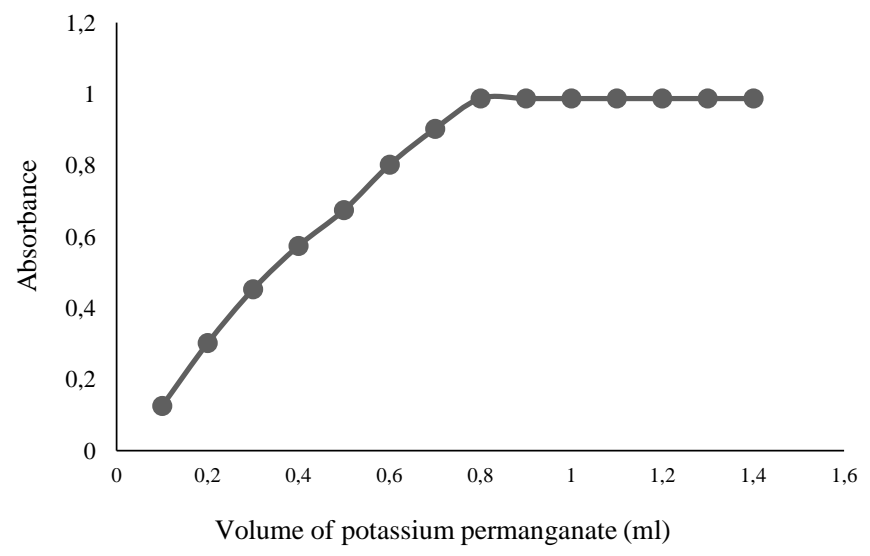

Figure 2: Effect of volume of potassium permanganate on the absorbance of green product.

\section{Effect of concentration of $\mathrm{NaOH}$}

The effect of the volume $(0.2-3.0 \mathrm{ml})$ of $\mathrm{NaOH}(1.8 \mathrm{M})$ was studied on the intensity coloured product, keeping constant $\mathrm{KMnO}_{4}\left(1.1 \times 10^{-4} \mathrm{M}\right)$ and metformin $(40 \mu \mathrm{g} / \mathrm{ml})$ concentration. The maximum absorbance was found with $2.4 \mathrm{ml} \mathrm{NaOH}$. Therefore, $2.7 \mathrm{ml}$ of $\mathrm{NaOH}(1.8 \mathrm{M})$ was used throughout the experiment (Figure 3).

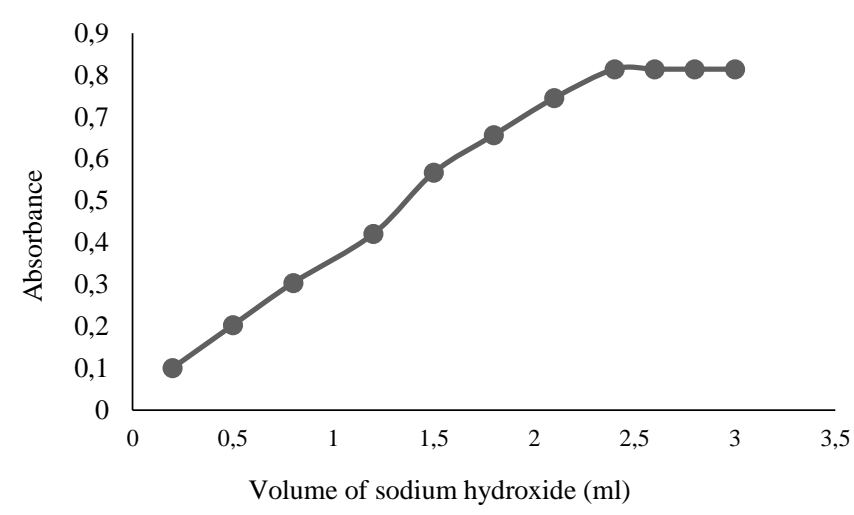

Figure 3. Effect of volume of sodium hydroxide on the absorbance of green product.

\section{RESULTS AND DISCUSSION}

The maximum absorption of potassium permanganate in basic medium exhibits at $530 \mathrm{~nm}$. The absorption spectrum of metformin showed in the ultraviolet range, generally at $233 \mathrm{~nm}$. However, the addition of $\mathrm{KMnO}_{4}$ to metformin in alkaline medium shifted its highest absorption band to $601 \mathrm{~nm}$. Because $\mathrm{KMnO}_{4}$ is a strong oxidizing agent and formed manganite ion. The oxidation no of Mn changes from +7 (purple) to +6 (green) and the metformin converted to metformin $\mathrm{N}-$ oxide $^{47}$ (Scheme 1). The colored product was measured after 5 minutes, and metformin can be determined in its pure solid form as well as in pharmaceutical formulations.

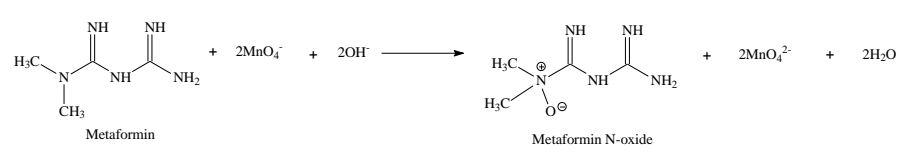

Scheme 1. The reaction mechanism for the formation of a green product.

\section{Vibrational IR spectrum Analysis}

The calculated vibrational wavenumber along with the experimental data, are presented in Table 1. The DFT calculation often overestimates the vibrational wavenumber and as such the overestimated vibrational wavenumbers obtained from B3LYP calculations were scaled by a factor of $0.9668 .{ }^{48}$ The assignment of vibrational modes obtained from the Potential Energy Distribution using the VEDA4 program ${ }^{49}$ is presented in the last column of Table 1. Metformin contains two imines $(\mathrm{C}=\mathrm{N}-\mathrm{H})$, primary amine, secondary amine and tertiary amine functional groups. The primary amine shows two $\mathrm{NH}$ bands in the range of $3500-3300 \mathrm{~cm}^{-1}$ corresponding to $\mathrm{NH}$ symmetric and asymmetric stretching while the secondary amine shows a band at around $3000 \mathrm{~cm}^{-1}$ corresponding to $\mathrm{NH}$ stretching. The $\mathrm{NH}$ stretching mode is usually observed around 3500 to $3300 \mathrm{~cm}^{-1} \cdot{ }^{50}$ In this study, the vibrational modes $\left(v_{1}-v_{5}\right)$ are attributed to the $\mathrm{NH}$ stretching. These modes are pure NH stretching with at least $97 \%$ contributions to PED. The vibrational $v_{1}$ and $v_{3}$ are attributed to $\mathrm{NH}$ asymmetric and symmetric stretching of the primary amine group of metformin. The $\mathrm{NH}$ vibrational mode of the secondary amine of metformin is observed at $3372 \mathrm{~cm}^{-1}$ and the modes $\left(v_{1}\right.$ and $v_{5}$ ) with $100 \%$ contributions to PED are attributed to the imine group. The vibrational modes $\left(v_{6}-v_{11}\right)$ are attributed to the $\mathrm{CH}$ stretching of the methyl groups of metformin. The $\mathrm{C}=\mathrm{N}$ stretching modes of metformin was observed at $1731 \mathrm{~cm}^{-1}$ which is typical of guanidine moiety. Guanidines show strong absorption due $\mathrm{C}=\mathrm{N}$ stretching at around $1685-1580 \mathrm{~cm}^{-1} .{ }^{50}$ The detailed descriptions of other vibrational modes are provided in the last column of Table 1. The vibrational infrared spectrum of the extracted metformin along with the simulated spectrum, are presented in Figure 4. The IR vibrational wavenumbers and their corresponding intensity are used to simulate the IR absorption spectrum of metformin. The simulated spectrum conforms with the experimental spectrum, and the figures illustrate the spectral characteristics of the metformin molecules as provided in Table 1 . 
Table 1. Experimental and calculated vibrational wavenumbers $\left(\mathrm{cm}^{-1}\right)$ of metformin.

\begin{tabular}{|c|c|c|c|c|c|}
\hline No. & Expt. & Cal & Scaled $^{\mathrm{a}}$ & Intensity $^{b}$ & Assignment $^{\mathrm{c}}(\mathrm{PED} \geq 10 \%)$ \\
\hline$v_{1}$ & - & 3651 & 3530 & 26.72 & vNH(99) \\
\hline$v_{2}$ & 3395 & 3615 & 3495 & 20.88 & vNH(98) \\
\hline$v_{3}$ & 3372 & 3548 & 3430 & 23.32 & $v \mathrm{NH}(97)$ \\
\hline$v_{4}$ & 3333 & 3524 & 3407 & 14.41 & $v \mathrm{NH}(100)$ \\
\hline$v_{5}$ & 3294 & 3517 & 3400 & 4.41 & $v \mathrm{NH}(100)$ \\
\hline$v_{6}$ & 3171 & 3146 & 3042 & 7.39 & vCH(89) \\
\hline$v_{7}$ & - & 3137 & 3033 & 17.48 & vCH(99) \\
\hline$v_{8}$ & - & 3075 & 2973 & 36.00 & $v \mathrm{CH}(93)$ \\
\hline$v_{9}$ & - & 3069 & 2967 & 29.50 & $\mathrm{vCH}(84)$ \\
\hline$v_{10}$ & 2931 & 3001 & 2901 & 62.91 & vCH(91) \\
\hline$v_{11}$ & 2970 & 2980 & 2881 & 62.57 & $v \mathrm{CH}(90)$ \\
\hline$v_{12}$ & 1636 & 1731 & 1674 & 384.50 & $\nu \mathrm{CN}(67)$ \\
\hline$v_{13}$ & 1620 & 1677 & 1621 & 215.87 & $v \mathrm{CN}(63)+\delta \mathrm{HCN}(12)$ \\
\hline$v_{14}$ & 1574 & 1626 & 1572 & 35.78 & $\delta \mathrm{HNH}(74)$ \\
\hline$v_{15}$ & - & 1528 & 1477 & 99.65 & $\delta \mathrm{HCH}(63)+\tau \mathrm{HCNC}(11)$ \\
\hline$v_{16}$ & - & 1506 & 1456 & 120.85 & $\delta \mathrm{HCN}(10)+\delta \mathrm{HCH}(50)+\tau \mathrm{HCNC}(10)$ \\
\hline$v_{17}$ & - & 1500 & 1450 & 330.24 & $v \mathrm{CN}(18)+\delta \mathrm{HCN}(25)+\delta \mathrm{HCH}(16)$ \\
\hline$v_{18}$ & 1473 & 1495 & 1445 & 19.82 & $\delta \mathrm{HCH}(60)+\tau \mathrm{HCNC}(13)$ \\
\hline$v_{19}$ & - & 1480 & 1431 & 37.37 & $\delta \mathrm{HCH}(56)+\tau \mathrm{HCNC}(14)$ \\
\hline$v_{20}$ & 1420 & 1474 & 1425 & 15.95 & $\delta \mathrm{HCH}(63)$ \\
\hline$v_{21}$ & 1404 & 1445 & 1397 & 2.10 & $\delta \mathrm{HCH}(82)$ \\
\hline$v_{22}$ & - & 1423 & 1376 & 28.19 & $v \mathrm{CN}(29)+\delta \mathrm{HNC}(24$ \\
\hline$v_{23}$ & - & 1340 & 1296 & 115.78 & $v \mathrm{CN}(18)+\delta \mathrm{HNC}(33)$ \\
\hline$v_{24}$ & 1291 & 1276 & 1234 & 87.18 & $v \mathrm{CN}(14)+\delta \mathrm{HNC}(18)+\tau \mathrm{HCNC}(10)$ \\
\hline$v_{25}$ & - & 1233 & 1192 & 13.47 & $v \mathrm{CN}(39)+\delta \mathrm{HNC}(10)+\tau \mathrm{HCNC}(16)$ \\
\hline$v_{26}$ & - & 1176 & 1137 & 44.46 & $\delta \mathrm{HNC}(68)$ \\
\hline$v_{27}$ & - & 1171 & 1132 & 13.68 & $\delta \mathrm{HCH}(18)+\tau \mathrm{HCNC}(60)$ \\
\hline$v_{28}$ & - & 1131 & 1093 & 161.75 & $v \mathrm{CN}(48)+\delta \mathrm{HNC}(36)$ \\
\hline$v_{29}$ & - & 1120 & 1083 & 3.64 & $\delta \mathrm{HCH}(13)+\tau \mathrm{HCNC}(61)$ \\
\hline$v_{30}$ & 1057 & 1097 & 1060 & 127.26 & $v \mathrm{CN}(33)+\delta \mathrm{HNC}(32)$ \\
\hline$v_{31}$ & 1049 & 1073 & 1038 & 14.25 & $v \mathrm{CN}(20)+\delta \mathrm{HCH}(13)+\tau \mathrm{HCNC}(42)$ \\
\hline$v_{32}$ & & 1035 & 1001 & 44.76 & $v \mathrm{CN}(55)+\tau \mathrm{HCNC}(11)$ \\
\hline$v_{33}$ & 933 & 949 & 917 & 12.76 & vCN(49) \\
\hline$v_{34}$ & - & 875 & 846 & 10.94 & $\tau \mathrm{HNCN}(83)$ \\
\hline$v_{35}$ & - & 864 & 835 & 22.60 & $v \mathrm{CN}(54)+\delta \mathrm{NCN}(12)$ \\
\hline$v_{36}$ & 802 & 800 & 774 & 43.28 & $\tau \mathrm{HNCN}(82)$ \\
\hline$v_{37}$ & 733 & 746 & 721 & 97.50 & $\tau \mathrm{HNCN}(65)$ \\
\hline$\nu_{38}$ & - & 727 & 702 & 13.13 & $\tau \mathrm{HNCN}(53)$ \\
\hline$v_{39}$ & 648 & 643 & 622 & 16.71 & $v \mathrm{CN}(16)+\delta \mathrm{NCN}(33$ \\
\hline$v_{40}$ & - & 612 & 592 & 178.34 & $\delta \mathrm{HNH}(10)+\tau \mathrm{HNCN}(64$ \\
\hline$v_{41}$ & 540 & 577 & 558 & 25.80 & $\delta \mathrm{NCN}(64)$ \\
\hline$v_{42}$ & 470 & 488 & 472 & 85.34 & $\tau \mathrm{HNCN}(70)$ \\
\hline
\end{tabular}

aScaled IR vibrational wavenumbers, $\mathrm{cm}^{-1}$ (scaled with 0.9668 ).

${ }^{\mathrm{b}}$ Calculated infrared intensities in $\mathrm{km} \mathrm{mol}^{-1}$.

${ }^{c} v$ is stretching, $\delta$ is bending, and $\tau$ is torsion. 


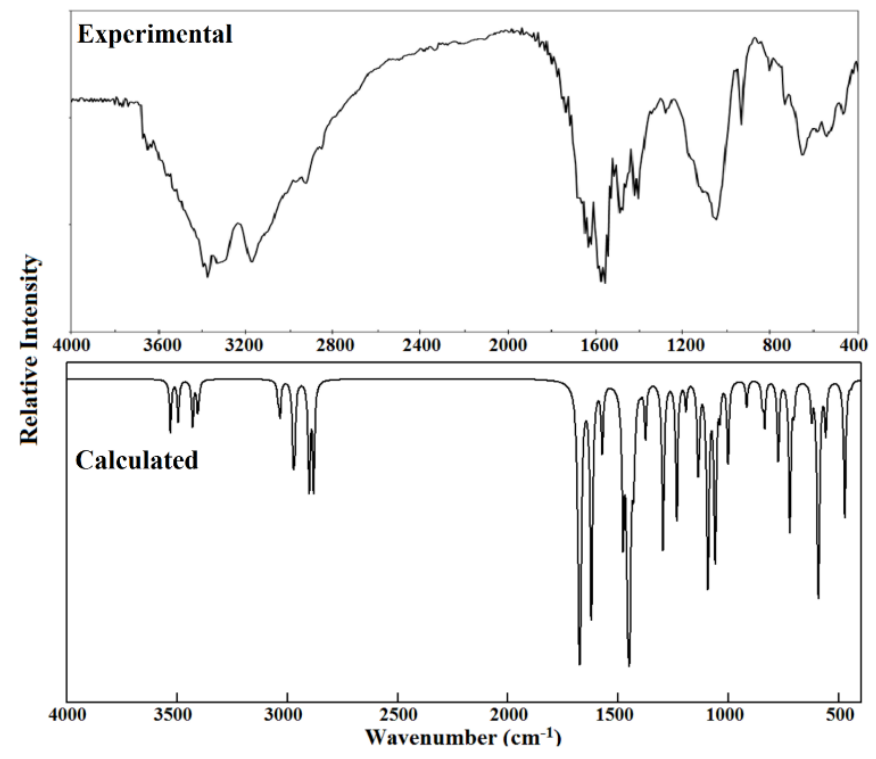

Figure 4. Experimental (top) and simulated (bottom) infrared spectra of metformin.

\section{Method validation}

According to the Food and Drug Administration (FDA), the developed method needs to validate as per USFDA regulations or followed the International Conference on Harmonization (ICH) guidelines. The parameters to validate a method are specificity/selectivity, linearity, linear range, accuracy, precision, limit of detection, limit of quantitation, ruggedness, and robustness. Validation is not only necessary for regulatory purposes, but it has a great demand for longterm analysis. The ICH guidelines discussed calculation and data interpretation for the present analysis and explained the importance of previous data for the future analysis. ${ }^{51-53}$

The concentration of metformin was linear in the range of $0.4-8.5 \mu \mathrm{g} / \mathrm{ml}$. The linear regression equation and optical parameters for quantification of metformin were tabulated in Table 2 . The intraday precision (within-day precision) was studied with corresponding concentration 2,4 and $6 \mu \mathrm{g} / \mathrm{ml}$ through replicate analysis $(\mathrm{n}=5)$ for metformin. Similarly, the interday precision was executed each day for consecutive five days with identical concentration as applied with withinday precision for the pure sample. The percentage recovery and relative standard deviation (RSD) were within the limit of $98-102 \%$ and $\pm 2 \%$ respectively. The percentage recovery and RSD values were 98-100.13, 0.298-0.722 and 99-100.27, 0.364-1.237, respectively, for intraday and interday precision (Table 3). Intraday and interday precision were continued with pharmaceutical dosage form with concentration 2,5 and $8 \mu \mathrm{g} / \mathrm{ml}$. The \% recovery and RSD values were in the range of 98.4-100.0, 0.210-1.159 and 98.2-100.6, 0.381-1.980 respectively for within-day and between-day precision in pharmaceutical formulations (Table 4). The results were satisfactory and showed its high accuracy for the proposed developed method.

Table 2. Summary of optical and regression characteristics of the proposed method.

\begin{tabular}{|l|l|}
\hline Parameters & Metformin hydrochloride \\
\hline Linear dynamic range $(\mu \mathrm{g} / \mathrm{ml})$ & $0.4-8.5$ \\
\hline Regression equation & $\mathrm{Y}=0.05 \mathrm{X}+0.003$ \\
\hline Correlation coefficient $\left(\mathrm{r}^{2}\right)$ & 0.9999 \\
\hline SD of the calibration curve $\left(\mathrm{S}_{\mathrm{o}}\right)$ & 0.002345 \\
\hline Slope of calibration curve $(\mathrm{b})$ & 0.0 .05 \\
\hline LOD $(\mu \mathrm{g} / \mathrm{ml})$ & 0.16 \\
\hline LOQ $(\mu \mathrm{g} / \mathrm{ml})$ & 0.47 \\
\hline
\end{tabular}

Table 3. Summary of accuracy and precision results of the proposed method.

\begin{tabular}{|c|c|c|c|c|c|c|}
\hline \multirow{2}{*}{$\begin{array}{c}\text { Proposed } \\
\text { methods }\end{array}$} & \multicolumn{2}{|c|}{ Amount $(\mu \mathrm{g} / \mathrm{ml})$} & \multirow[t]{2}{*}{$\begin{array}{c}\% \\
\text { Recovery }\end{array}$} & \multirow[t]{2}{*}{$\begin{array}{c}\% \\
\text { RSD }^{\mathrm{a}}\end{array}$} & \multirow[t]{2}{*}{$\mathbf{S A E}^{\mathbf{b}}$} & \multirow[t]{2}{*}{$\mathbf{C L}^{\mathrm{c}}$} \\
\hline & Taken & Found \pm SD $^{\mathrm{a}}$ & & & & \\
\hline \multirow{3}{*}{ Intraday } & 2 & $1.96 \pm 0.014$ & 98.0 & 0.722 & 0.0063 & 0.0176 \\
\hline & 4 & $3.99 \pm 0.023$ & 99.7 & 0.572 & 0.0102 & 0.0283 \\
\hline & 6 & $6.01 \pm 0.018$ & 100.13 & 0.298 & 0.008 & 0.022 \\
\hline \multirow{3}{*}{ Interday } & 2 & $1.98 \pm 0.025$ & 99.0 & 1.237 & 0.011 & 0.030 \\
\hline & 4 & $3.99 \pm 0.023$ & 99.7 & 0.572 & 0.0102 & 0.0283 \\
\hline & 6 & $6.02 \pm 0.022$ & 100.27 & 0.364 & 0.01 & 0.028 \\
\hline
\end{tabular}

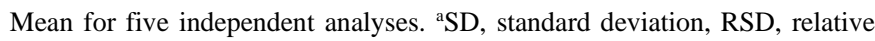

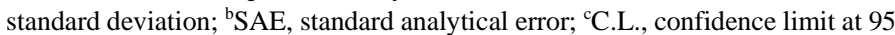
$\%$ confidence level and 4 degrees of freedom $(t=2.776)$.

Table 4. Summary of accuracy and precision results of the proposed method in pharmaceutical formulations.

\begin{tabular}{|c|c|c|c|c|c|c|}
\hline \multirow{2}{*}{$\begin{array}{c}\text { Proposed } \\
\text { methods }\end{array}$} & \multicolumn{2}{|c|}{ Amount $(\mu \mathrm{g} / \mathrm{ml})$} & \multirow{2}{*}{$\begin{array}{c}\% \\
\text { Recovery }\end{array}$} & \multirow{2}{*}{$\begin{array}{c}\% \\
\text { RSD }^{\mathrm{a}}\end{array}$} & \multirow{2}{*}{$\mathbf{S A E}^{\mathbf{b}}$} & \multirow{2}{*}{$\mathbf{C L}^{\mathrm{c}}$} \\
\hline & Taken & Found $\pm \mathrm{SD}^{\mathrm{a}}$ & & & & \\
\hline \multirow{3}{*}{$\begin{array}{c}\text { Intraday } \\
\text { Dialon }\end{array}$} & 2 & $1.968 \pm 0.023$ & 98.4 & 1.159 & 0.0102 & 0.0283 \\
\hline & 5 & $4.96 \pm 0.032$ & 99.2 & 0.638 & 0.0141 & 0.0393 \\
\hline & 8 & $7.976 \pm 0.017$ & 99.7 & 0.210 & 0.0075 & 0.0208 \\
\hline \multirow{3}{*}{ Metfor } & 2 & $1.998 \pm 0.022$ & 99.4 & 1.147 & 0.0102 & 0.0283 \\
\hline & 5 & $4.964 \pm 0.039$ & 99.28 & 0.775 & 0.0172 & 0.0478 \\
\hline & 8 & $8.00 \pm 0.0378$ & 100.0 & 0.468 & 0.0167 & 0.0465 \\
\hline \multirow{3}{*}{$\begin{array}{c}\text { Glucare } \\
\text { XR }\end{array}$} & 2 & $1.976 \pm 0.016$ & 98.8 & 0.847 & 0.0074 & 0.0207 \\
\hline & 5 & $5.008 \pm 0.042$ & 99.7 & 0.828 & 0.0185 & 0.0515 \\
\hline & 8 & $7.976 \pm 0.046$ & 99.7 & 0.572 & 0.0204 & 0.0566 \\
\hline \multirow{3}{*}{$\begin{array}{c}\text { Interday } \\
\text { Dialon }\end{array}$} & 2 & $2.012 \pm 0.030$ & 100.6 & 1.508 & 0.0136 & 0.0377 \\
\hline & 5 & $4.968 \pm 0.039$ & 99.36 & 0.785 & 0.0174 & 0.0484 \\
\hline & 8 & $7.968 \pm 0.030$ & 99.6 & 0.381 & 0.0136 & 0.0377 \\
\hline \multirow{3}{*}{ Metfor } & 2 & $2.020 \pm 0.040$ & 101.0 & 1.980 & 0.0179 & 0.0497 \\
\hline & 5 & $4.992 \pm 0.046$ & 99.84 & 0.922 & 0.0206 & 0.0572 \\
\hline & 8 & $7.960 \pm 0.047$ & 99.50 & 0.589 & 0.021 & 0.058 \\
\hline \multirow{3}{*}{$\begin{array}{c}\text { Glucare } \\
\text { XR }\end{array}$} & 2 & $1.964 \pm 0.026$ & 98.20 & 1.328 & 0.0117 & 0.0324 \\
\hline & 5 & $4.996 \pm 0.052$ & 99.92 & 1.036 & 0.0232 & 0.0643 \\
\hline & 8 & $7.972 \pm 0.059$ & 99.65 & 0.744 & 0.0265 & 0.0737 \\
\hline
\end{tabular}

Mean for five independent analyses. ${ }^{\text {aSD }}$, standard deviation, RSD, relative

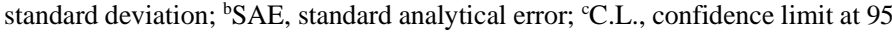
$\%$ confidence level and 4 degrees of freedom $(\mathrm{t}=2.776)$.

The proposed method was used for estimating at the metformin from the tablet after spiking with 50,100 and $150 \%$ of additional pure drug, respectively. The results are reported in Table 5. It can be seen from Table 5 that the recovery and RSD values were in the ranges $98.27-100.40 \%$ and $0.334-1.35 \%$ respectively. The selectivity of the proposed method was evaluated by incorporating magnesium stearate, microcrystalline cellulose, polydextrose, titanium dioxide into standard pure drug solutions. It was observed that the excipients did not interfere with the proposed method. 
Table 5. Summary of data for the determination in pharmaceutical preparations by the standard addition method.

\begin{tabular}{|c|c|c|c|c|c|c|}
\hline \multirow{2}{*}{$\begin{array}{l}\text { Proposed } \\
\text { methods }\end{array}$} & \multicolumn{3}{|c|}{ Amount $(\mu \mathrm{g} / \mathrm{ml})$} & \multirow{2}{*}{$\begin{array}{c}\% \\
\text { Recovery }\end{array}$} & \multirow{2}{*}{$\begin{array}{c}\% \\
\text { RSD }^{\mathrm{a}}\end{array}$} & \multirow{2}{*}{ SAE ${ }^{b}$} \\
\hline & Taken & Added & Found \pm SD $^{a}$ & & & \\
\hline \multirow{3}{*}{ Dialon } & 2 & 1 & $2.948 \pm 0.036$ & 98.27 & 1.23 & 0.016 \\
\hline & 2 & 2 & $3.968 \pm 0.045$ & 99.20 & 1.05 & 0.019 \\
\hline & 2 & 3 & $4.964 \pm 0.030$ & 98.28 & 0.59 & 0.013 \\
\hline \multirow{3}{*}{ Metfor } & 2 & 1 & $2.960 \pm 0.040$ & 98.67 & 1.350 & 0.018 \\
\hline & 2 & 2 & $3.988 \pm 0.023$ & 98.70 & 0.572 & 0.010 \\
\hline & 2 & 3 & $4.976 \pm 0.033$ & 99.52 & 0.660 & 0.015 \\
\hline \multirow{3}{*}{$\begin{array}{c}\text { Glucare } \\
\text { XR }\end{array}$} & 2 & 1 & $3.012 \pm 0.011$ & 100.40 & 0.360 & 0.005 \\
\hline & 2 & 2 & $3.992 \pm 0.023$ & 99.80 & 0.571 & 0.010 \\
\hline & 2 & 3 & $5.004 \pm 0.017$ & 100.08 & 0.334 & 0.008 \\
\hline
\end{tabular}

Mean for five independent analyses. ${ }^{\text {a }} \mathrm{SD}$, standard deviation, RSD, relative

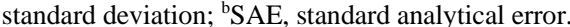

\section{CONCLUSION}

Spectrophotometric method was applied for the routine quality control analysis of metformin in pharmaceutical formulations. The quantification of metformin in the literature shows that higher instrumental methods require more pretreatment as well as separation procedure. However, the conventional method like the extractive spectrophotometric method for determination metformin is effective as well are tedious, time-consuming, but the problem it requires a large amount of sample and reagents with possible contamination and losses of the analyte. Therefore, the present method can be a better alternate for quantification of metformin in pure form and pharmaceutical formulation. The extracted metformin was confirmed using the IR spectroscopy, and the spectrum shows vibrational modes that are in agreement with the simulated IR spectrum. The vibrational modes were reliably assigned based on potential energy distribution.

\section{REFERENCES}

1. American Diabetes Association, Standards of medical care for patients with diabetes mellitus (Position Statement), Diabetes Care 26 (Suppl. 1), S33, (2003).

2. W. Chen, D. Desai, D. Good, J. Crison, P. Timmins, S. Paruchuri, J. Wang, K. Ha, AAPS PharmSciTech 17, 1007, (2015).

3. A.J. Krentz, C.J. Bailey, Drugs, 65, 385, (2005).

4. R.A. DeFronzo, N. Barzilai, D.C. Simonson, J. Clin. Endocrinol. Metab. 73, 1294, (1991).

5. C.J. Bailey, R.C. Turner, Metformin, N. Engl. J. Med. 334, 574, (1996).

6. N. Musi, M.F. Hirshman, J. Nygren, M. Svanfeldt, P. Bavenholm, O. Rooyackers, G. Zhou, J.M. Williamson, O. Ljunqvist, S. Efendic, D.E. Moller, A. Thorell, L.J. Goodyear, Diabetes 2002; 2074:51, (2002).

7. G. Rena, E. Pearson, K. Sakamoto, Diabetologia, 56, 1898 (2013).

8. M. Musutova, M. Elkalaf, N. Klubickova, M. Koc, S. Povysil, J. Rambousek, B. Volckaert, F. Duska, M.D. Trinh, M. Kalous, J. Trnka, K. Balusikova, J. Kovar, J. Polak, Front. Endocrinol. 9, 616, (2018).

9. R. Andayani, F. Pitasari, Rusdi, J. Chem. Pharma. Res. 7, 159, (2015)

10. D.K. Modi, P.B. Parejiya, B.H. Patel. J. Chem. 2013, 139561, (2013).

11. K.B. Ahir, E.M. Patelia, A. Shah, J. Chromat. Separation Techniq. 4, 166, (2013).

12. G.M. Ben-Hander, A.A.A. Abdusalam, B. Saad, A. Makahleh, S.M. Salhimi. Chem. Sci. Int. J. 26, 1, (2019).

13. K.S. Lakshmi, T. Rajesh, S. Sharma, Int. J. Pharm. Pharma. Sci. 1, 162, (2009).

14. P. Umapathi, J. Ayyappan, S.D. Quine, Trop. J. Pharma. Res. 11, 107, (2012).

15. H.P. Chhetri, P. Thapa, A.V. Schepdael, Saudi Pharma. J. 22, 483, (2014).

16. P. Vemula, D. Dodda, U. Balekari, S. Panga, C. Veeresham, J. Adv. Pharm. Technol. Res. 6, 25, (2015)

17. S.S. Aslan, B. Y1lmaz. American J. Anal. Chem, 8, 541, (2017).
18. A. Gedawy, H. Al-Salami, C.R. Dass, J. Food Drug Anal. 27, 315, (2019).

19. Y.R. Mary, V. Sudha, A.K.H. Kumar, Chromatogr. Separation Techniq. J. 2, 119, (2019).

20. S.S. Chalikwar, D.R. Shah, P.S. Jain, Anal. Chem. Ind. J. 16, 115, (2016),

21. S.R. Polagani, N.R. Pilli, R. Gajula, V. Gandu, J. Pharma. Anal. 3, 9, (2013).

22. G. Mubeen, K. Noor. Indian J. Pharm. Sci. 71, 100, (2009).

23. N.R. Ahmad, Iraqi National J. Chem. 46, 161, (2012).

24. K. Basavaiaha, N. Rajendraprasad, Anal. Bioanal. Chem. Res. 4, 41, (2017).

25. Y.D. Dange, S.M. Honmane, S.D. Bhinge, V.R. Salunkhe, D.R. Jadge, Indian J. Pharma. Education Res. 51, S754, (2017).

26. R.V. Rele, P.P. Tiwatane, Asian J. Res. Chem. 12, 351, (2019).

27. M.R. Sohrabi, N. Kamali, M. Khakpour, Anal. Sci. 27, 1037, (2011).

28. T.T. Chungath, Y.P. Reddy, N. Devanna. Int. J. PharmTech Res. 3, 2064, (2011)

29. R. Karim, N. Poly, R. Banoo, Int. J. Pharm. Sci. Res. 3, 3170, (2012).

30. A.B. Loni, M.R. Ghante, SD. Sawant, Der Pharma Chemica, 4, 854, (2012).

31. R. Bhaskar, R. Bhaskar, M.K. Sagar, V. Saini, K.M. Bhat, Pharma. Anal. Acta 3, 158, (2012).

32. A.R. Rote, R.B. Saudagar, World J. Pharm. Sci. 2014 2(12): 1841 (2014).

33. AD Mali, S. Mali, A. Tamboli, R. Bathe, Int. J. Adv. Pharma. 4, 117, (2015).

34. K. Ganesh, G. Nikitha, D. Sireesha, B. Vasudha, Int. J. Appl. Pharm. Sci. Res. 1, 56, (2016).

35. Y.D. Dange, S.M. Honmane, S.D. Bhinge, V.R. Salunkhe, D.R. Jadge, Indian J. Pharma. Edu. Res. 51(4S), S754, (2017).

36. M. Harde, S. Lakade, V. Gite, V. Chopade, A. Khomne, Int. Res. J. Pharm. $10,90,(2019)$

37. Y. Umar, N. Abu-Thabit, P. Ramasami, J. Theor. Comp. Chem. 18 1950009, (2019).

38. Y. Umar, J. Tijani, S. Abdalla, J. Struct. Chem. 60, 186, (2019).

39. Y. Umar, S. Abdalla, J. Sol. Chem, 4, 741, (2017).

40. Y. Umar, J. Tijani, S. Abdalla, J. Structural Chem. 57, 1543, (2016)

41. P.H. Yeoh, K.Z. Lim, E.L. Tan, L. Rhyman, Y. Umar, H.H. Abdallah, P. Ramasami, J. Sol. Chem. 45, 1195, (2016).

42. S. Abdalla, Y. Umar, I. Mokhtar, Zeitschrift für Physikalische Chemie, 230, 867, (2016).

43. Y. Umar, Spectrochem. Acta A. Molecular. Biomolecular Spectros. 71, 1907, (2009).

44. A.D. Becke, J. Chem. Phys. 98, 5648, (1993).

45. C. Lee, W. Yang, R.G. Parr, Physical Review B 37, 785, (1988).

46. M.J. Frisch, G.W. Trucks, H.B. Schlegel, G.E. Scuseria, M.A. Robb, J.R. Cheeseman, G. Scalmani, V. Barone, B. Mennucci, G.A. Petersson, H. Nakatsuji, M. Caricato, X. Li, H.P. Hratchian, A.F. Izmaylov, J. Bloino, G. Zheng, J.L. Sonnenberg, M. Hada, M. Ehara, K. Toyota, R. Fukuda, J. Hasegawa, M. Ishida, T. Nakajima, Y. Honda, O. Kitao, H. Nakai, T. Vreven, J.A. Montgomery, J.E. Peralta, F. Ogliaro, M. Bearpark, J.J. Heyd, E. Brothers, K.N. Kudin, V.N. Staroverov, R. Kobayashi, J. Normand, K. Raghavachari, A. Rendell, J.C. Burant, S.S. Iyengar, J. Tomasi, M. Cossi, N. Rega, J.M. Millam, M. Klene, J.E. Knox, J.B. Cross, V. Bakken, C. Adamo, J. Jaramillo, R. Gomperts, R.E. Stratmann, O. Yazyev, A.J. Austin, R. Cammi, C. Pomelli, J.W. Ochterski, R.L. Martin, K. Morokuma, V.G. Zakrzewski, G.A. Voth, P. Salvador, J.J. Dannenberg, S. Dapprich, A.D. Daniels, O. Farkas, J.B. Foresman, J.V. Ortiz, J. Cioslowski, D.J. Fox, Gaussian 09, Revision 02, Gaussian, Inc., Wallingford CT, 2009.

47. N. Rahman, H. Rahman, S.M. Haque, Arabian J. Chem, 10 (Suppl 1), S831, (2017).

48. A.P. Scott, L. Radom, J. Phys. Chem. 100,16502, (1996)

49. M.H. Jamroz, Vibrational Energy Distribution Analysis: VEDA 4 Program Warsaw, 2004

50. R.M. Silverstein, F.X. Webster, Spectrometric identification of organic compounds, Sixth edition, John Wiley and Sons, Inc. USA, 1998.

51. Department of health and human services, center for drug evaluation and research (CDER) US: center for veterinary medicine (CVM). Food and drug administration of the United States, guidance for industry-bioanalytical method validation, 2001 .

52. International conference on the harmonization of the technical requirements for registration of pharmaceuticals for human use (ICH) Q2A: validation of analytical methods, definitions, and terminology, 1994.

53. International conference on the harmonization of the technical requirements for registration of pharmaceuticals for human use ICH: Q2B analytical validation-methodology, 1996. 